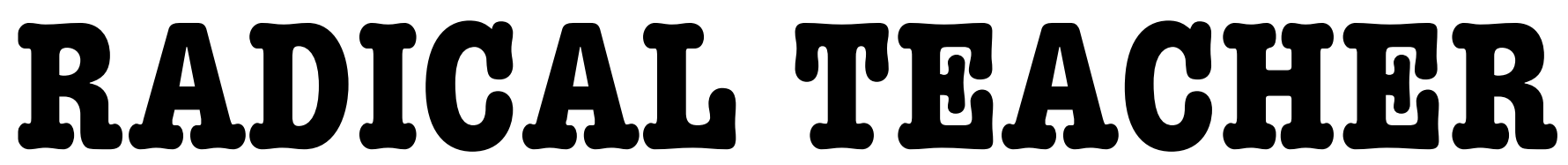

A SOCIALIST, FEMINIST, AND ANTI-RACIST JOURNAL ON THE THEORY AND PRACTICE OF TEACHING

\title{
The Quiet American
}

(RADICAL TEACHER NO.31, 1986)

by Sanford Radner

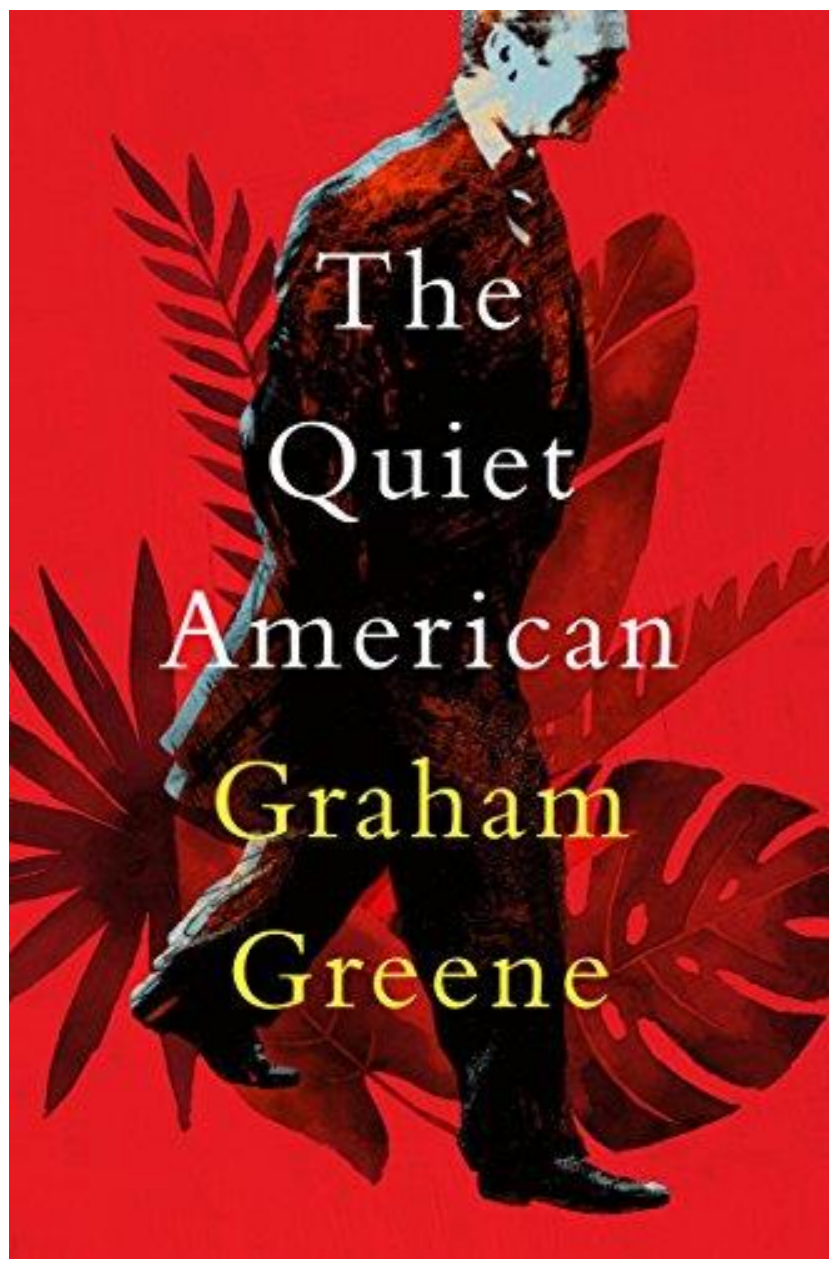

THE QUIET AMERICA BY GRAHAM GREENE (HEINEMANN, 1955) 
The Quiet American. Graham Greene. Penguin Books.

$\mathrm{I}$

n some eras (our own Reagan 1980s, for example) political radicalization is often accomplished most effectively by indirection. Greene's 1955 novel is a case in point: set in Vietnam on the eve of the French expulsion, it fronts as a love story and skillfully-contrived murder mystery. These elements initially grabbed most of the students in a seminar I recently taught on the 20th century English novel. This group was largely made up of yuppies-in training and actual suburban housewives; politics was not their main interest in the study of imaginative literature. Yet, in the final class discussion on the book, issues such as past American involvement in Vietnam and, especially, the possibilities of future intervention in Nicaragua dwarfed all "literary" matters. At the end of the semester, The Quiet American was voted most meaningful by my students, over such modern classics as Joyce's Portrait and Lawrence's Sons and Lovers.

Actually, the personal love story and the political plot which describes covert American meddling right before the fall of Dienbienphu are beautifully integrated in this novel. Greene's view is that sexism, racism, real politik -- all are underscored by a common nefarious triad: manipulation, deception, and the threat of violence. Pyle, the protagonist, is an American secret agent: in looks, thinking, speech, and action - a young Ronald Reagan. In attempting to woo the native woman, Phuong, away from her longtime lover, Pyle uses this triad, much in the same manner as, acting professionally, he operates to create a "third force" between the French and the Vietnamese. In both private and public realms, the sanctimonious stink of White American male moralism is redolent: "I wanted to protect her." In the end, Phuong doesn't succumb to Pyle's "dollar love," and he becomes the victim of his own political intrigue.

Skillfully crafted, politically prophetic, this is also a short readable book, appropriate for non-literature majors as writing motivation in Freshman Composition courses, or part of a genre Introduction to Literature approach. I paired it (in an anti-imperialism unit) with Burmese Days, Orwell's look at the same area a quarter century earlier; Tim O'Brien's fine Going After Cacciato articulates with Greene on the other end, massive American killing and dying in Vietnam in the 1970s.

(c) EY-NC-ND

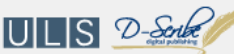

This work is licensed under a Creative Commons Attribution-Noncommercial-No Derivative Works 3.0 United States License.

This journal is published by the University Library System of the University of Pittsburgh as part of its D-Scribe Digital Publishing Program, and is cosponsored by the University of Pittsburgh Press. 